\title{
Role of Iron in Regulation of Virulence Genes
}

\author{
CHRISTINE M. LITWIN ${ }^{1}$ AND STEPHEN B. CALDERWOOD ${ }^{1,2 *}$ \\ Infectious Disease Unit, Massachusetts General Hospital, Boston, Massachusetts 02114, ${ }^{1 *}$ and \\ Department of Microbiology and Molecular Genetics, Harvard Medical School, \\ Boston, Massachusetts $02115^{2}$
}

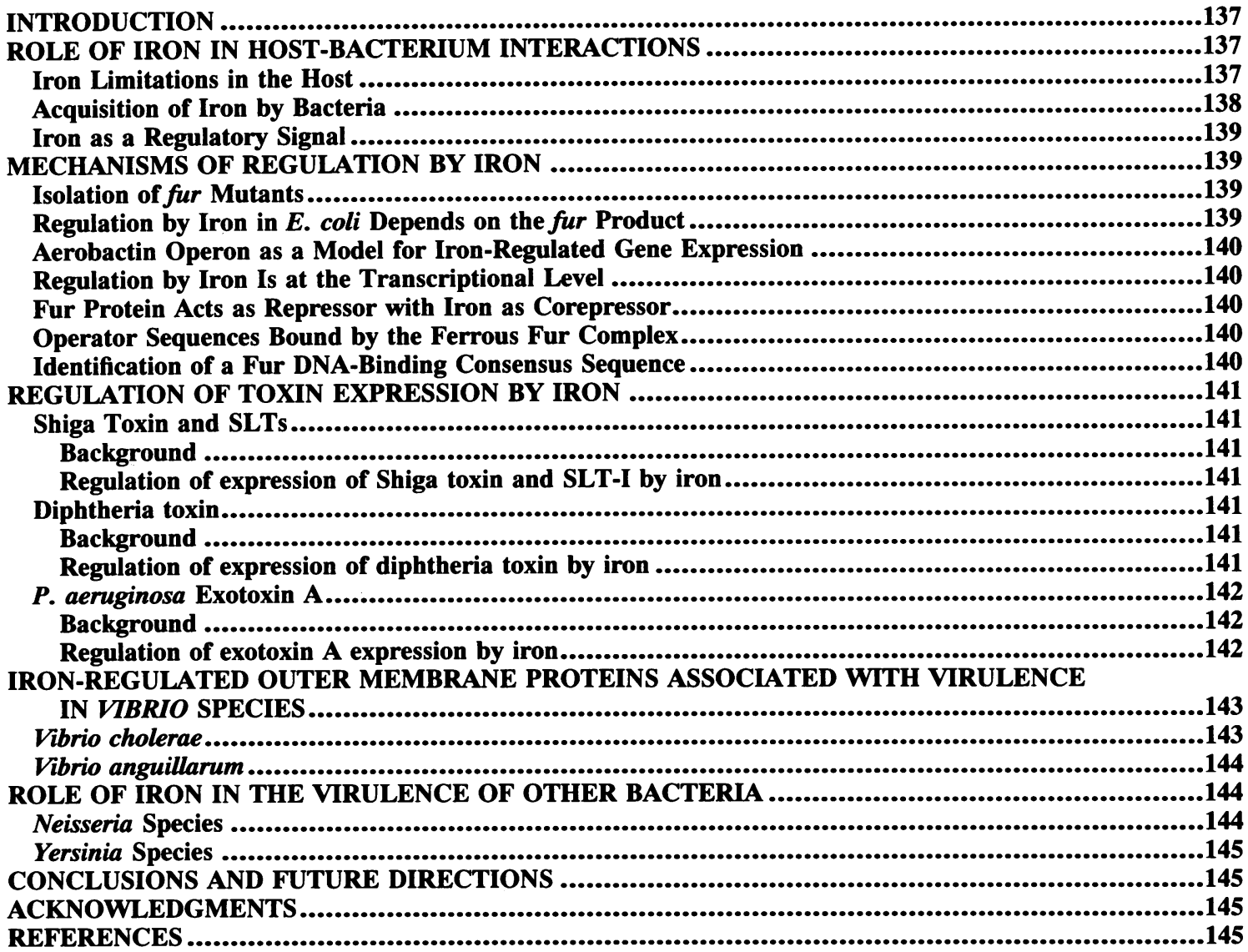

\section{INTRODUCTION}

Iron is an important element essential to the growth of almost all living cells (108). Iron is needed for important cellular functions, such as the transport and storage of oxygen, and as a catalyst in electron transport processes. Since iron has an extremely wide redox potential, spanning approximately $1 \mathrm{~V}$, it is a very versatile biocatalyst. A variety of enzymes that require iron for activity have been characterized; these include ribotide reductase, nitrogenase, peroxidase, catalase, cytochromes, and succinic dehydrogenase. These enzymes serve important cellular roles, such as the reduction of ribonucleotides and dinitrogen and the activation and decomposition of peroxides.

Iron is abundant in the earth's crust, being the fourth most common element. Yet in the presence of oxygen, iron is oxidized to the ferric state and may form ferric hydroxide, which is insoluble in aqueous solution at neutral or alkaline

\footnotetext{
* Corresponding author.
}

$\mathrm{pH}$ and thus is not readily accessible to bacteria (109). Because of iron's insolubility, microorganisms have evolved a number of mechanisms for the acquisition of adequate iron from the environment; these mechanisms are closely linked to bacterial virulence. The competitive growth and survival of bacteria in the host require a number of adaptive responses on the part of the bacteria; the acquisition of iron is one of the most important of these adaptive responses for bacterial pathogenesis.

\section{ROLE OF IRON IN HOST-BACTERIUM INTERACTIONS}

\section{Iron Limitations in the Host}

Free iron is extremely limited in the mammalian host, making acquisition of iron by invading pathogens especially difficult. The human body contains as much as 3 to $5 \mathrm{~g}$ of iron, but the majority of this iron is not easily accessible to bacteria. Iron is maintained in a soluble form by being complexed to carrier molecules or reduced to ferrous iron 
within cells. Most intracellular iron is found as hemoglobin, heme, ferritin, and hemosiderin. The trace quantities of iron present extracellularly are bound by the high-affinity ironbinding glycoproteins transferrin and lactoferrin (4). In normal human serum, the amount of free iron in equilibrium with transferrin-bound iron has been calculated by Bullen et al. (27) to be approximately $10^{-18} \mathrm{M}$. This is far below the level required to support bacterial growth (27). Unsaturated transferrin appears to contribute to the bacteriocidal activity of normal human plasma (152), while lactoferrin may serve a similar function on secretory surfaces and is also an important component of phagocytic cells (149). Extracellular hemoglobin and heme have been found to serve as iron sources for many bacteria; however, they are rapidly bound by two serum proteins, haptoglobin and hemopexin, respectively, and are removed from the circulation $(49,159)$.

During infection, iron availability is further limited by the induction of hypoferremia, which has long been recognized as a component of the acute-phase response to infection. This acute-phase response, which can be induced by microbes and certain microbial products such as endotoxin, is mediated through the increased release of various cytokines, particularly interleukin-1 and tumor necrosis factor alpha (cachectin) $(12,45)$. The iron saturation in serum decreases with an accompanying increase in the level of transferrin, limiting iron availability for bacteria $(105,154)$. Lactoferrin levels are also increased in the blood during an inflammatory response. The release of apolactoferrin by leukocytes occurs during degranulation and phagocytosis, which additionally increases the local concentration of lactoferrin at sites of infection $(88,162)$.

A number of studies have shown enhanced resistance to infection in animals in which levels of iron in serum have been reduced by an iron-deficient diet. This enhanced resistance to infection is reversed if the iron-deficient mice are injected with sufficient iron to restore normal levels of iron in serum $(73,123)$.

If hypoferremia limits infection, then chronic iron overload might be expected to increase susceptibility to infection. Numerous studies have demonstrated that injection of exogenous iron to produce iron overload in animals enhances susceptibility to bacterial infection $(26,56,58,125$, 161). This effect of excessive iron has been noted in human diseases as well, such as in primary and secondary hemochromatosis. An association between iron overload and increased risk of bacteremia has been noted for several bacterial species, including Vibrio vulnificus (17), Yersinia enterocolitica (98), and Escherichia coli $(8,9)$. Excessive iron may enhance infection by reversing iron limitation and stimulating the growth of bacteria. Alternatively, others have suggested that iron overload may interfere with host defense mechanisms such as cell-mediated immunity (85) and the bacteriocidal activity of leukocytes (64). Thus, it may be difficult to separate the contribution of iron overload in stimulating bacterial growth from its contribution in interfering with host defense mechanisms.

\section{Acquisition of Iron by Bacteria}

For pathogenic bacteria to be able to establish an infection, they must be able to obtain iron from the host. Because iron is limiting in the host, a number of diverse mechanisms have been evolved by bacteria either to free iron from host sources or to utilize host iron-binding compounds directly. Many bacteria secrete low-molecular-weight, high-affinity iron chelators termed siderophores in response to iron stress $(109,110)$. These siderophores can solubilize iron from mineral complexes in the environment and can compete effectively with the host iron-binding compounds transferrin and lactoferrin to mobilize iron for bacterial use. Subsequent transport of the iron-siderophore complexes into the bacterium requires cell surface receptors specific for each siderophore complex. Other pathogenic bacteria secrete reductants (38), which remove ferric iron from transferrin, or utilize citrate as a low-affinity iron carrier (62).

Some bacterial species utilize host iron complexes directly to enhance bacterial growth, without the production of siderophores. Neisseria spp., for example, possess specific receptors for ferric transferrin and can remove iron from transferrin at the cell surface (100). Yersinia pestis can use heme as a sole source of iron for growth (121), $V$. vulnificus can use the hemoglobin-haptoglobin complex (74), and Haemophilus influenzae can utilize hemoglobin, hemoglobinhaptoglobin, heme-hemopexin, and heme-albumin (140).

Another mechanism for iron acquisition by bacteria is the production of hemolysins, which release iron complexed to intracellular heme and hemoglobin. Synthesis of such hemolysins is frequently regulated by iron availability, with increased expression when iron is limiting $(136,150)$. Production of hemolysins is common among pathogenic bacteria but has been studied most thoroughly in $E$. coli (132).

An association between pathogenicity of $E$. coli and the production of $\alpha$-hemolysin has been reported in a number of studies. Minshew et al. found that $80 \%$ of $E$. coli strains virulent in chicken embryos were hemolytic (103). Waalwijk et al. studied the role of hemolysins in $E$. coli by using a hematogenous pyelonephritis model in mice and found that a nonhemolytic avirulent $E$. coli strain was restored to virulence by simultaneous injection of the avirulent mutant with its hemolytic and virulent parent or with partially purified hemolysin (150). Linggood and Ingram similarly found that transfer of a plasmid encoding hemolysin to a nonhemolytic strain of $E$. coli increased the virulence of the recipient for mice. Injection of hemolysin, hemoglobin, iron, or manganese salts simulated the effect of the hemolysin plasmid (90). Various studies with clinical isolates of $E$. coli have demonstrated a statistical correlation between hemolysin production and recovery from blood and urine but not with recovery from stool. In a study of $223 \mathrm{E}$. coli isolates, Deboy et al. found that hemolytic strains were isolated more often from blood, urine, and wounds than from stools (41). In a study of 167 patients, Brooks et al. found that $58 \%$ of $E$. coli strains isolated from upper urinary tract infections produced hemolysin, but only $27 \%$ of strains isolated from the lower urinary tract did so (24). A collection of $115 \mathrm{E}$. coli strains isolated from women and children with acute nonobstructive pyelonephritis was compared with 96 fecal isolates; hemolysin synthesis, production of cytotoxic necrotizing factor, and aerobactin-mediated iron uptake occurred more often in strains from patients with pyelonephritis (145).

Hemolysins appear to promote infection by providing iron to the pathogen in vivo $(90,150)$. Opal et al. (117) compared the production of the siderophore, aerobactin, and hemolysin in E. coli strains isolated from blood, urine, and stool. The majority $(55 \%)$ of blood isolates that lacked aerobactin production were hemolytic, suggesting that the hemolysin serves as an alternative mechanism of iron acquisition in the absence of aerobactin (117). 
TABLE 1. Examples of iron-regulated bacterial virulence determinants

\begin{tabular}{ll}
\hline \multicolumn{1}{c}{ Organism } & \multicolumn{1}{c}{ Virulence determinant(s) } \\
\hline Escherichia coli & Aerobactin \\
& SLT-I \\
& $\alpha-$ Hemolysin \\
Shigella dysenteriae type 1 & Shiga toxin \\
Serratia marcescens & Hemolysin \\
Vibrio cholerae & Iron-regulated gene $A$ (irgA) \\
Vibrio anguillarum & Anguibactin \\
Yersinia spp. & Iron-regulated outer membrane proteins \\
Neisseria gonorrhoeae & Transferrin-binding protein 1 (TBP1) \\
& Transferrin-binding protein 2 (TBP2) \\
Pseudomonas aeruginosa & Exotoxin A \\
& Elastase \\
Corynebacterium diphtheriae & Alkaline protease \\
\hline
\end{tabular}

\section{Iron as a Regulatory Signal}

For effective bacterial pathogenesis, the organism must sense its environment appropriately and respond with coordinate alterations in the expression of virulence genes. A number of environmental factors, including $\mathrm{pH}$, osmolarity, temperature, and amino acid concentration, coordinately regulate the expression of virulence genes (102). Since free iron is extremely limited in the mammalian host, a shift from a high- to a low-iron environment is an important environmental signal to bacteria for coordinate regulation of gene expression. As summarized above, hemolysins and siderophores have been implicated as virulence factors in several model systems and are regulated by the concentration of iron in the environment $(24,39,41,90,150,157)$. Other virulence factors regulated by the concentration of iron include Shiga toxin from Shigella dysenteriae I, Shiga-like toxin I (SLT-I) from enterohemorrhagic $E$. coli, diphtheria toxin from Corynebacterium diphtheriae, exotoxin A from Pseudomonas aeruginosa, and a number of iron-regulated outer membrane proteins. Examples of iron-regulated virulence determinants are provided in Table 1. These virulence determinants and the role of iron in their regulation will be discussed in greater detail below.

\section{MECHANISMS OF REGULATION BY IRON}

\section{Isolation of fur Mutants}

The molecular basis of coordinate regulation by iron has been most thoroughly studied in $E$. coli. In this organism, coordinate regulation of gene expression by iron depends on a single regulatory gene, fur. Mutations of fur were found first in Salmonella typhimurium by Ernst et al., who were studying unrelated periplasmic leaky $(l k y)$ mutants. A secondary mutation that led to the overproduction of ironregulated outer membrane proteins and was termed fur, for ferric uptake regulation, was found (54). This mutation also resulted in constitutive production and transport of the siderophore enterobactin as well as constitutive uptake of the siderophore ferrichrome.

Hantke (71) first obtained fur mutants of $E$. coli by screening for constitutive expression of a $\mathrm{Mu} \mathrm{d}(\mathrm{Ap}-\mathrm{lac})$ fusion to the ferrichrome transport gene, fhuA, following use of the chemical mutagen $N$-methyl- $N^{\prime}$-nitro- $N$-nitrosoguanidine. The fur mutants constitutively expressed all iron uptake systems, including the uptake of uncomplexed iron. The fur mutants were also unable to grow on several nonfermentable carbon sources, including acetate, succinate, and fumarate (6); the fur gene may be allelic to $d c t B$, which is believed to be involved in succinate transport. Hantke (72) cloned the fur gene by screening an E. coli recombinant plasmid library for complementation of the fur mutation. Minicell analysis showed that the fur gene encoded an approximately $18-\mathrm{kDa}$ protein. The gene was subsequently sequenced and shown to encode a 148-aminoacid (17-kDa) protein with a high histidine content (129).

\section{Regulation by Iron in $E$. coli Depends on the fur Product}

Transcriptional regulation of genes in $E$. coli by iron is mediated by the protein product of the fur locus, which acts as a corepressor with ferrous iron via sequence-specific protein-DNA interactions at the promoter regions of Furregulated genes. Table 2 lists the functions of many of the iron-regulated genes in $E$. coli, most of which have also been shown to be Fur regulated. The aerobactin operon (iuc $A B C D$

TABLE 2. Iron-regulated genes in E. coli ${ }^{a}$

\begin{tabular}{|c|c|c|}
\hline Gene(s) & Location (min) & Function \\
\hline fhuA $(\operatorname{ton} A)$ & 3 & Outer membrane receptor, ferric hydroxamate siderophores \\
\hline fhuBCD & 3 & Transport, ferric hydroxamate siderophores \\
\hline fecA & 6 & Outer membrane receptor, ferric dicitrate \\
\hline$f e c B C D E$ & 6 & Ferric dicitrate transport \\
\hline ent $A B C D E F$ & 13 & Enterobactin biosynthesis \\
\hline fep $A$ & 13 & Outer membrane receptor, ferric enterobactin \\
\hline fepBCDEG & 13 & Ferric enterobactin transport \\
\hline fes & 13 & Ferric enterobactin esterase (reductase) \\
\hline fur & 16 & Repressor, ferric uptake regulation \\
\hline fhuE & 16 & Outer membrane receptor, coprogen and ferric rhodotorulate \\
\hline $\mathrm{fiu}$ & 18 & Unknown \\
\hline $\operatorname{ton} B$ & 27 & Transport of ferric siderophores, vitamin $B_{12}$, and lethal agents \\
\hline cir & 43 & Colicin I transport \\
\hline $\operatorname{exb} b C$ & 64 & Transport of ferric siderophores, vitamin $B_{12}$, and lethal agents \\
\hline iutA & pColV & Outer membrane receptor, ferric aerobactin \\
\hline iuc $A B C D$ (aerDBCA, respectively) & pColV & Aerobactin biosynthesis \\
\hline slt-I & Phage H-19B & Shiga-like toxin I \\
\hline
\end{tabular}

${ }^{a}$ Adapted from reference 111 with permission. 
iut $A$ ) has been used as a model for studying the regulation of gene expression in $E$. coli by iron.

\section{Aerobactin Operon as a Model for Iron-Regulated Gene Expression}

Strains of $E$. coli containing the plasmid pColV, which were characterized by their capacities to cause invasive disease in experimental animals, were the first strains described (by Williams [157]) as producing the bacteriocin colicin $\mathrm{V}$ as well as a novel siderophore. The genetic determinants for the bacteriocin and the siderophore were localized to this $\mathrm{V}$ (virulence) plasmid (157). Williams and Warner showed that the virulence characteristic was attributed to the plasmid-encoded siderophore system rather than to colicin $\mathrm{V}$ or to the chromosomally encoded enterobactin system (158). The siderophore produced in the presence of the $\mathrm{V}$ plasmid pColV-K30 was subsequently isolated and shown to be aerobactin (153). Genes encoding the production of aerobactin have subsequently been shown to be chromosomal in Shigella species (87), in some Salmonella species (96), and in certain $E$. coli, including $E$. coli K1 (147) and enteroinvasive strains (94). Unlike $E$. coli ColV strains, whose virulence is greatly enhanced by the presence of the aerobactin system, an aerobactin mutant of Shigella flexneri retained its virulence (86). This difference may be related to the fact that $E$. coli ColV strains are associated with septicemic infections, while Shigella flexneri strains produce a predominantly intracellular infection.

The entire high-affinity, aerobactin-mediated iron assimilation system of pColV-K30 was cloned by Bindereif et al. (14). The iron-regulated aerobactin gene cluster was shown to be organized in an operon consisting of four biosynthesis genes, iuc $A B C D$, and a transport gene, iut $A$ (43).

\section{Regulation by Iron Is at the Transcriptional Level}

S1 nuclease protection assays specific to RNA from the aerobactin operon revealed the presence of major and minor transcriptional start sites immediately upstream from iuc $A$, the first gene in the aerobactin cluster of pColV-K30. A quantitative $\mathrm{S} 1$ protection assay demonstrated that regulation of the aerobactin promoter by iron occurs directly at the transcriptional level. Following growth in high-iron conditions, no RNA initiating at the major promoter (P1) could be detected, while under iron starvation conditions, specific RNA was detected. The use of a lacZ transcriptional fusion to the aerobactin promoter also demonstrated that repression of aerobactin gene expression by iron occurs at the transcriptional level (13).

\section{Fur Protein Acts as Repressor with Iron as Corepressor}

Experiments performed in vivo to ascertain the effects of divalent manganese, iron, and cobalt on the expression of $\beta$-galactosidase in E. coli BN407 (pColV iucC::lacZ) showed that each of these divalent cations represses $\beta$-galactosidase activity expressed from the aerobactin promoter. Cloning of the fur gene in an overexpression vector allowed the purification of the Fur protein for in vitro studies (6). An in vitro transcription-translation system utilizing the lac $Z$ fusion demonstrated specific regulation of transcription of the aerobactin operon by $\mathrm{Mn}(\mathrm{II})$ and $\mathrm{Fe}(\mathrm{II})$. In subsequent work, $\mathrm{Mn}(\mathrm{II})$ was used as an activator of Fur because of its stability in the presence of oxygen (7).

A Hill plot was generated from the repression of $\beta$-galac-

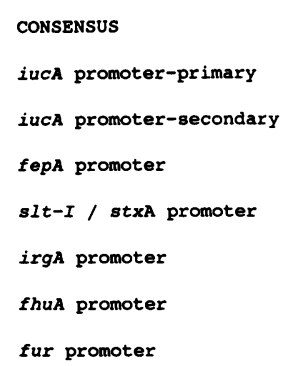

CONSENSUS

iucA promoter-primary

iucA promoter-secondary

fepA promoter

sIt-I / stXA promoter

irgA promoter

fhuA promoter

fur promoter

$\overrightarrow{\text { GAT AAT GAT A }} \underset{\text { ATC ATT ATC }}{\longrightarrow}$

GAT AAT GAG A ATC ATT ATT

GAT AAT TGT T ATT ATT TTA

TAT TAT GAT A ACT ATT TGC

GAA TAT GAT T ATC ATT TTC

GAA ATT AAG A ATA ATT ATC

CTT TAT Aat A ATC ATT CTC

TAT Aat Gat a CGC ATT ATC
FIG. 1. Homology between the dyad repeat sequences in various iron-regulated promoters and the Fur-binding consensus sequence of $E$. coli. Arrows indicate dyad symmetry in the consensus sequence.

tosidase activity as a function of Fur concentration. The slope of 2 was consistent with the hypothesis that the Fur repressor acts as a dimer (6). A negative complementation experiment, in which $E$. coli strains heterozygous for both the wild type and certain mutant alleles of fur retained a Fur ${ }^{-}$phenotype, provided further evidence that Fur is active in vivo as a multimer (22).

\section{Operator Sequences Bound by the Ferrous Fur Complex}

In DNase I protection experiments, the Fur protein, activated by divalent heavy-metal ions including $\mathrm{Mn}$ (II), $\mathrm{Fe}(\mathrm{II}), \mathrm{Co}(\mathrm{II})$, and $\mathrm{Cd}(\mathrm{II})$, was found to bind and protect a specific nucleotide sequence overlapping the $\mathrm{P} 1$ promoter in the aerobactin operon of pColV-K30 (44). In the absence of divalent cations, Fur had very little capacity for binding the operator.

DeLorenzo et al. (44) performed DNA footprint experiments with the purified Fur protein with $\mathrm{Mn}(\mathrm{II})$ as corepressor. The Fur protein bound to two contiguous sites. With excess $\mathrm{Mn}(\mathrm{II})$, increasing the level of Fur first protected a sequence bracketing the -35 region of the P1 promoter, which was designated the primary binding site, and then an additional secondary binding site located just downstream of the -10 region. The primary and secondary binding sites had in common the sequence ATAATnnnnATnATT. The primary site extended over $31 \mathrm{bp}$ and consisted of two overlapping symmetrical dyads sharing the sequence 5'-TCATT$3^{\prime}$.

\section{Identification of a Fur DNA-Binding Consensus Sequence}

Using the data from the defined aerobactin promoter and genetic data from the iron-regulated promoter of SLT-I (see below), several investigators independently proposed a consensus "iron box" for binding of the Fur repressor $(29,42$, 44). This proposed iron box is a perfect 19-bp hyphenated dyad repeat. The promoters of $\operatorname{sit}-L A, \operatorname{iuc} A, f e p A, \operatorname{ing} A$, and fhu $A$ show homology with this consensus sequence that ranges from 13 to 17 base-pair matches (Fig. 1). Homology to the iron box is also found in the promoter region of the $E$. coli fur gene itself, raising the possibility that there may be autoregulation of fur by iron (44). Bases in the iron boxes shown in Fig. 1 which are invariant from the consensus sequence include the $T$ at position 6 and ATT at positions 14 to 16 . The remaining bases in the iron boxes match the consensus sequence in four to six of the promoters shown in Fig. 1.

On the basis of the evidence presented above, the mech- 
Inactive Fur Repressor

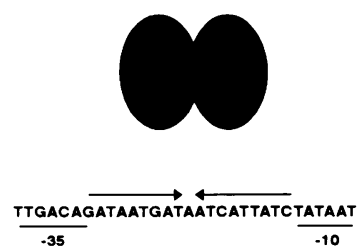

Active Fur Repressor

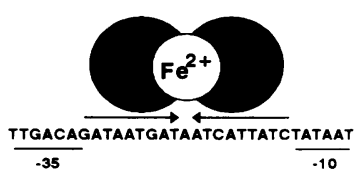

FIG. 2. Schematic representation of iron regulation by Fur in $E$. coli. The Fur-binding site overlaps the promoters of iron-regulated genes. $\mathrm{Fe}^{2+}$ acts as a corepressor with Fur at sufficient intracellular concentrations of iron. The active Fur-iron complex binds to the Fur-binding site and prevents transcription.

anism by which iron concentration regulates gene expression in $E$. coli can be schematically represented by the model depicted in Fig. 2. The consensus Fur-binding site is located near or within the promoter of iron-regulated genes. $\mathrm{Fe}^{2+}$ is a corepressor such that at sufficient intracellular concentrations of iron the Fur-iron complex binds DNA at the iron box and prevents transcription of the iron-regulated gene.

\section{REGULATION OF TOXIN EXPRESSION BY IRON}

\section{Shiga Toxin and SLTs}

Background. Shiga toxin from $S$. dysenteriae, E. coli SLT-I, SLT-II, and the $E$. coli pig edema disease toxin SLT-IIv constitute a group of closely related proteins that have similar biological activities and homologous amino acid sequences. Within this group, only Shiga toxin and SLT-I are regulated by iron. The biological activities of these toxins include cytotoxicity for certain tissue culture cell lines, neurotoxicity and lethality after injection into mice, and enterotoxicity in the ligated rabbit ileal loop assay $(50,113)$.

Shiga toxin produced by $S$. dysenteriae serotype 1 was discovered in 1903 by Conradi (36). In 1982, O'Brien et al. reported that certain strains of enterohemorrhagic $E$. coli produced similar toxins that were neutralized by antisera to Shiga toxin and named such toxins Shiga-like toxins (SLTs) (114). SLT-producing $E$. coli have been epidemiologically associated with hemorrhagic colitis $(81,115)$ and the hemolytic uremic syndrome in humans (84). Subsequently, the SLT family has been divided into SLT-I (neutralized by anti-Shiga toxin antibody) and SLT-II (not neutralized) (139); the related pig edema disease toxin has been defined as a variant of SLT-II (95).

The deduced amino acid sequences of Shiga toxin and SLT-I are highly homologous $(28,138)$, while those of SLT-II and SLT-IIv are more divergent (95). Mature Shiga toxin is composed of a single $31-\mathrm{kDa}$ A subunit and multiple 7.7-kDa B subunits (116) with a stoichiometry of 1:5 (46). Mild trypsin cleavage of the A subunit results in a $27-\mathrm{kDa} A 1$ fragment that is catalytically active and inhibits protein synthesis by inactivation of the $60 \mathrm{~S}$ ribosomal subunit (116, 124). Shiga toxin, SLT-I, SLT-II, and SLT-IIv all have the same mechanism of action as the A chain of ricin, i.e., cleaving a specific adenine residue from the 28S rRNA component of the $60 \mathrm{~S}$ eukaryotic ribosomal subunit (51-53, $128)$. This RNA $N$-glycosidase activity rapidly inhibits protein synthesis.

Regulation of expression of Shiga toxin and SLT-I by iron. Dubos and Geiger demonstrated that Shiga toxin from
S. dysenteriae was produced in lesser amounts when an excess of iron was present in the culture medium (47). Van Heyningen and Gladstone also studied the effects of iron on Shiga toxin production and showed that iron deficiency enhanced production of the toxin (148).

The molecular mechanism of regulation by iron has been examined in detail for the SLT-I of $E$. coli. Calderwood and Mekalanos used gene fusions between the promoter proximal slt- $L A$ gene and TnphoA to study regulation of SLT-I expression by iron (29). Using the alkaline phosphatase activity of the gene fusion as a recorder, they demonstrated that iron represses SLT-I expression. When the gene fusion was transferred into a fur mutant strain of $E$. coli, iron no longer decreased SLT-I expression, suggesting that the Fur protein served as a repressor for the SLT-I operon. Deletion analysis of the slt-I promoter localized the region necessary for regulation of slt-I expression by iron and Fur. A 21-bp dyad repeat identified in this region was homologous to similar dyads in the promoter regions of three other ironregulated genes in E. coli (29) (Fig. 1). Primer extension with RNA from a strain carrying the SLT-I operon cloned on a multicopy plasmid identified a transcriptional start site (42) compatible with the promoter proposed by Calderwood and Mekalanos. Semiquantitative primer extension experiments showed that this RNA transcript was greatly increased under conditions of iron starvation (42). These data led three groups of investigators $(29,42,44)$ to propose a common consensus sequence for the binding of Fur to iron-regulated promoters (Fig. 1) Calderwood and Mekalanos subsequently confirmed this proposed consensus sequence by introducing it as a synthetic oligonucleotide into a heterologous promoter and showing that the oligonucleotide was sufficient to confer iron regulation (30). Since the sequence of the Shiga toxin operon (138) is nearly identical to that of SLT-I, it is likely that regulation of Shiga toxin expression by iron occurs by the same mechanism as regulation of SLT-I expression. In contrast, genes that encode expression of SLT-II and SLT-IIv are not regulated by iron and do not contain the Fur-binding consensus sequence in their promoter regions (141).

\section{Diphtheria Toxin}

Background. Diphtheria toxin from $C$. diphtheriae belongs to a class of secreted bacterial toxins that transfer the ADP-ribose moiety of $\mathrm{NAD}^{+}$onto specific target proteins within mammalian cells $(35,79,80)$. Pseudomonas exotoxin $\mathrm{A}$ is another member of this class, and both of these toxins are regulated by the concentration of iron in the environment. Despite the similar intracellular mechanisms of action of diphtheria toxin and Pseudomonas exotoxin A, these toxins are associated with different disease processes, probably because of different target cell specificities (101).

Regulation of expression of diphtheria toxin by iron. Diphtheria toxin is synthesized by strains of $C$. diphtheriae that are lysogenic for one of a family of corynebacteriophages carrying the structural gene for the toxin, tox $(25,146)$. Pappenheimer and Johnson first observed in 1936 that addition of iron to the growth medium inhibited the production of diphtheria toxin by $C$. diphtheriae (119). More recently, a siderophore of $C$. diphtheriae that is coordinately regulated with diphtheria toxin by iron has been described $(126,143)$.

Several investigators have shown that regulation of diphtheria toxin expression by elevated levels of iron in the growth medium occurs at the level of transcription $(82,89)$. Evidence for both cis-and trans-acting regulatory elements 
responsive to iron has been presented. Evidence for a cis-acting (operator) site in the tox gene itself was suggested by the isolation of corynebacteriophage mutants in which tox expression was insensitive to iron $(107,155)$. Evidence that iron regulation of tox expression also requires a negative trans-acting bacterial factor was suggested by the isolation of bacterial mutants in which tox expression from a number of different corynebacteriophages was also insensitive to iron (83). These biochemical and genetic observations supported the hypothesis proposed by Murphy and Bacha that the corynebacteriophage tox gene is regulated by an ironbinding repressor encoded by the bacterial host (106).

The putative tox operator locus has been identified as a 27-bp region that contains inverted repeated sequences separated by 9 bp (20). This putative tox operator locus shares some homology with the $E$. coli Fur-binding consensus sequence. Fourel et al. identified an iron-binding protein in extracts of $C$. diphtheriae, which they named DtoxR, that could bind to the presumptive tox operator locus and protect it from DNase I digestion (59). Tai and Holmes reported that the $E$. coli Fur protein partially regulated expression of a tox::galK transcriptional fusion in which the tox regulatory region and the coding sequence for fragment $A$ and a portion of fragment B of diphtheria toxin were cloned upstream of a promoterless galK gene (142). In $E$. coli, the expression of this tox::galK fusion was repressed approximately fivefold under iron-sufficient conditions, and this repression appeared to depend on the E. coli fur gene (142).

Boyd et al. cloned the trans-acting tox regulatory element from $C$. diphtheriae by using a tox promoter-operator (toxPO)-lacZ transcriptional fusion introduced into the chromosome of $E$. coli (21). This strain was used to screen a genomic library of nontoxigenic, nonlysogenic $C$. diphtheriae for clones that would repress lac $Z$ expression in the presence of iron. The diphtheria tox iron-regulatory gene $d t x R$ was cloned in this fashion and shown to regulate the expression of $\beta$-galactosidase from the toxPO::lacZ fusion in an iron-dependent manner. They found that $d t x R$ was homologous to the $E$. coli fur gene at both the nucleotide $(66 \%)$ and amino acid sequence $(25 \%)$ levels. Schmitt and Holmes, however, performed an independent analysis of nucleotide and deduced amino acid homologies between $d t x R$ and fur with the Genetics Computer Group sequence analysis program and found less homology, only $39 \%$ identity at the nucleotide level and $18 \%$ identity at the amino acid level, under optimal sequence alignment (130). Boyd et al. found that the expression of the toxPO::lacZ fusion was not repressed by $E$. coli fur in trans, and the presence of $d t x R$ did not inhibit expression of the iron-regulated outer membrane proteins of $E$. coli (21). The limited homology between the deduced amino acid sequences of DtxR and Fur is consistent with the finding that complementation between these proteins is weak (142) or absent (21). These data suggest that, despite similar mechanisms of action by both DtxR and Fur, their iron-regulatory activities are restricted to the specific operator-binding sites characteristic of their species of origin.

\section{P. aeruginosa Exotoxin A}

Background. Of the numerous extracellular proteins produced by $P$. aeruginosa, including exoenzyme $\mathrm{S}$, elastase, alkaline protease, phospholipase $\mathrm{C}$, and leukocidin, exotoxin $A$ is the most toxic and appears to be an important virulence factor in this opportunistic pathogen (160). The expression of exotoxin $A$ is regulated in a temporal manner and by numerous environmental factors. Toxin production is enhanced late in the growth cycle and by aeration, glycerol, or growth at $32^{\circ} \mathrm{C}(92)$. The divalent cations $\mathrm{Fe}^{2+}, \mathrm{Co}^{2+}$, $\mathrm{Cu}^{2+}$, and $\mathrm{Mn}^{2+}$ inhibit exotoxin A expression, while $\mathrm{Mg}^{2+}$ and $\mathrm{Zn}^{2+}$ have no effect (19). $\mathrm{Ca}^{2+}$ increases exotoxin $\mathrm{A}$ yields (19). The regulation of exotoxin A production is thus complex and appears to require the participation of a number of gene products in response to environmental stimuli.

Regulation of exotoxin $A$ expression by iron. In $P$. aeruginosa, iron limitation derepresses the synthesis of not only the siderophores pyochelin and pyoverdin but also a number of virulence factors, including exotoxin $\mathrm{A}$, elastase, and alkaline protease $(15,16)$. Exotoxin A production usually decreases 10 -fold when clinical isolates of $P$. aeruginosa are grown in iron-containing medium $(15,16)$. Bjorn et al. (15) postulated that iron either decreased the rate of synthesis of exotoxin A or increased the rate of its degradation.

Sokol et al. identified several iron-regulatory mutants of $P$. aeruginosa PAO1 by selecting for strains that still produced elastase or exotoxin A when grown in medium supplemented with iron (133). Mutants insensitive to the effect of iron on the production of exotoxin $\mathrm{A}($ tox $C)$ or of elastase $($ ela $C)$ fell into two classes: mutants with mutations in iron uptake and mutants with gene expression altered in response to iron. In the first class of mutants, one strain, PAO-Fe10, produced normal amounts of pyochelin and pyoverdin but was deficient in the transport of these siderophores and inorganic iron. Another mutant, PAO-Fe11, overproduced exotoxin A but was deficient in the production of pyoverdin. These mutants suggested that defects in iron acquisition by $P$. aeruginosa could result in the overproduction of gene products that are normally repressed under high-iron conditions. In the second class of mutants, some produced exotoxin $\mathrm{A}$ in high-iron conditions (toxC), but alkaline protease and elastase expression remained sensitive to iron. Other mutants produced elastase in high-iron conditions (elaC), but expression of exotoxin $\mathrm{A}$ and alkaline protease remained iron regulated. These data suggested that exotoxin A, elastase, and alkaline protease expression could be independently regulated by iron.

Several studies have suggested that regulation of exotoxin A expression by iron occurs at the level of transcription (60, $61,69,93)$. In addition, transcription of $\operatorname{tox} A$ requires the product of a positive regulatory gene, $\operatorname{reg} A$, which is itself negatively regulated by iron (76). The $\operatorname{reg} A$ transcript appears earlier in the growth cycle than the tox $A$ transcript, and $\operatorname{RegA}$ is required for maximal $\operatorname{tox} A$ transcription. When transcription of $\operatorname{reg} A$ is inhibited by high-iron conditions, transcription of tox $A$ is similarly reduced (76).

Frank and Iglewski have performed more detailed experiments on reg $A$ expression in response to iron (60). They reported two reg $A$ transcripts, one (called $\mathrm{T} 1$ ) occurring early in the growth phase and not tightly regulated by iron and the other (called T2) occurring later in the growth phase and tightly regulated by iron. Northern (RNA) blot analysis suggested that the two $\operatorname{reg} A$ transcripts, $\mathrm{T} 1$ and $\mathrm{T} 2$, originated from different start sites. Analysis of tox $A$ transcription showed a similar pattern of growth phase and iron regulation, providing further evidence that regulation of $\operatorname{tox} A$ transcription by iron reflects regulation of the positive transcriptional activator $\operatorname{reg} A$.

Regulation of $\operatorname{tox} A$ and $\operatorname{reg} A$ transcription was studied further by using $P$. aeruginosa PA103 containing the $\operatorname{reg} A$ gene on a multicopy plasmid (61). There were still two phases of $r e g A$ transcript accumulation, a $\mathrm{T} 1$ (early phase) and a T2 (late phase) transcript. However, no effect of iron 
on the accumulation of the $\mathrm{T} 1$ transcript was seen, while accumulation of the T2 transcript was still completely inhibited in high-iron conditions. Primer extension analysis confirmed that $\operatorname{reg} A$ transcription is controlled by two separate promoters, P1 and P2, which correspond to transcripts T1 and T2, respectively. Transcription from the $\mathrm{P} 1$ promoter is not tightly regulated by iron, while transcription from $P 2$ is. Regulation of transcription from the $\mathrm{P} 2$ promoter by iron late in the growth phase is responsible for iron regulation of exotoxin A expression.

Storey et al. have shown that the $\operatorname{reg} B$ gene, which is downstream of the $\operatorname{reg} A$ gene in an operon, is required for transcription from the $\mathrm{P} 1$ promoter (137). Transcription from the $\operatorname{reg} A B$ operon, therefore, is autoregulated, and production of RegB from the T1 transcript early in the growth cycle is required for maximal synthesis of exotoxin $\mathrm{A}$, while later in the growth cycle, transcription from the $\mathrm{P} 2$ promoter (T2 transcript) is RegB independent and iron regulated.

Analysis of the sequences upstream of the two start sites for $\operatorname{reg} A$ transcription reveals little homology between the proposed $\mathrm{P} 1$ and $\mathrm{P} 2$ promoters. The $\mathrm{P} 2$ promoter contains a region (TTGATT) 24 bp upstream of the T2 start site with limited homology to the consensus -35 box of $E$. coli (TTGACA) but with perfect homology to the -35 region of the iron-regulated diphtheria toxin promoter. Similarly, the -10 region of the $\mathrm{P} 2$ promoter (TAGGGT) is highly homologous to the -10 region of the diphtheria toxin promoter (TAGGAT). On the basis of these observations, a common mechanism for iron regulation of exotoxin $A$ and diphtheria toxin can be postulated (60).

Recent evidence suggests that negative regulation of gene expression in $P$. aeruginosa by iron is mediated by a Fur homolog. Prince et al. (122) introduced a multicopy plasmid containing the $E$. coli fur gene into $P$. aeruginosa PA103C, which contains a tox $A$ ::lac $Z$ fusion integrated into the chromosome. Normally, $\beta$-galactosidase expression in strain PA103C is regulated by iron, but this activity remained repressed even under low-iron conditions in the presence of multiple copies of the $E$. coli fur gene. Transcription of regA was similarly repressed under low-iron conditions when multiple copies of the $E$. coli fur gene were present. A polyclonal rabbit antiserum to $E$. coli Fur recognized a similarly sized protein in whole-cell extracts of $P$. aeruginosa, thus providing direct evidence of a Fur homolog (122).

Prince et al. (122) also found by Northern (RNA) blot analysis that multiple copies of $E$. coli fur inhibited transcription from the $\mathrm{P} 1$ promoter, which presumably leads to expression of RegA and RegB, but did not repress transcription from the P2 promoter. This contrasts with the findings by Frank and Iglewski (60) and Storey et al. (137), who found that the $\mathrm{P} 1$ promoter of $\mathrm{reg} A$ was not tightly regulated by iron and the $\mathrm{P} 2$ promoter was active later in the growth cycle and tightly regulated by iron. The data by Prince et al. suggest that iron regulation of transcription from P2 is not regulated by $E$. coli Fur. The mechanism by which $E$. coli Fur affects reg $A$ transcription is unclear, and further clarification will require the cloned $P$. aeruginosa fur gene.

\section{IRON-REGULATED OUTER MEMBRANE PROTEINS ASSOCIATED WITH VIRULENCE IN VIBRIO SPECIES}

\section{Vibrio cholerae}

IrgA is an outer membrane protein described recently as an iron-regulated virulence determinant in $V$. cholerae.
Identification of IrgA followed TnphoA mutagenesis to obtain insertion mutations in several iron-regulated genes of $V$. cholerae $\mathrm{O} 395$ and subsequent assay of these transposon mutant strains for virulence defects (68). One such mutant strain had lost the 77-kDa major iron-regulated outer membrane protein of $V$. cholerae and was attenuated for virulence; the $50 \%$ lethal dose of this mutant in suckling mice was $3 \times 10^{5}$ bacteria compared with $4 \times 10^{3}$ bacteria for the wild-type parent. An in vivo competitive assay between the mutant and the parent suggested a possible colonization defect.

To define the mechanism of regulation of $i r g A$ expression by iron, the 5 '-proximal portion of irg $A$ was cloned and sequenced, and the promoter region was defined by primer extension (66). Regulation of irg $A$ expression by iron occurred at the transcriptional level. An interrupted dyad symmetric nucleotide sequence was identified in the vicinity of the promoter that was homologous to the consensus Fur-binding site in $E$. coli (Fig. 1). Unlike transcription of iron-regulated genes in $E$. coli, however, transcription of ing $A$ required an additional 900 bp of upstream DNA that contained an open reading frame in inverse orientation to ing $A$.

Transcription of this upstream open reading frame was also negatively regulated in $V$. cholerae by iron (67), and this gene was designated $\operatorname{irg} B$. Insertional inactivation of $\operatorname{irg} B$ on the $V$. cholerae chromosome led to loss of expression of an ing $A$ ::Tnpho $A$ fusion; expression of the fusion was restored to normal when irg $B$ was present on a plasmid in trans. The predicted protein product of $i r g B(\operatorname{IrgB})$ is homologous to the LysR family of positive transcriptional activators (75). The promoters of $\operatorname{ing} B$ and irg $A$ are divergent but overlap each other and the dyad sequence homologous to the $E$. coli Fur-binding site. A model for iron regulation of $i r g A$ expression was proposed on the basis of these studies. In the presence of sufficient iron, transcription of both $\operatorname{ing} A$ and ing $B$ is repressed by the Fur protein of $V$. cholerae. When iron becomes limiting, negative regulation of transcription is removed and the production of IrgB leads to positive transcriptional activation of $i n g$.

The complete sequence of ing $A$ is now available and demonstrates that IrgA is homologous to the TonB-dependent outer membrane transport proteins of $E$. coli (65). Despite this homology, however, a mutant of irg $A$ is not defective in the transport of any known iron source for $V$. cholerae, including vibriobactin, ferrichrome, ferric citrate, hemin, or hemoglobin. Gene sequences hybridizing at high stringency to an ing $A$ probe are found in several Vibrio species, including non-O1 V. cholerae, Vibrio parahaemolyticus, Vibrio fluvialis, and Vibrio alginolyticus. Whether $\operatorname{irg} A$ is a virulence gene in these other species is unknown, as is the role of $\operatorname{IrgA}$ in the pathogenesis of $V$. cholerae infection.

The observations that ing $A$ is iron regulated in an $E$. coli background and that the $E$. coli gene slt- $L A$ is reciprocally iron regulated in a $V$. cholerae background suggest that the mechanism of regulation by iron in $V$. cholerae is similar to the $E$. coli Fur system (66). Another study supporting this hypothesis was provided by Stoebner and Payne, who described a mutant strain of $V$. cholerae in which iron regulation of the soluble hemolysin and synthesis of the siderophore vibriobactin had been lost (136). Regulation of these genes by iron was restored when the $E$. coli fur gene was introduced into the mutant on a plasmid.

The fur gene of $E$. coli has been used recently as a probe to recover the intact fur gene of $V$. cholerae. Southern 
hybridization of $V$. cholerae chromosomal DNA probed with a DNA fragment internal to the $E$. coli fur gene under conditions of low stringency showed single hybridizing bands with a number of restriction enzymes that allowed development of a restriction map around the hybridizing region in $V$. cholerae (91). The $V$. cholerae fur gene was recovered, and the intact cloned gene was able to complement an E. coli fur mutation. Primer extension analysis localized two promoters for the $V$. cholerae fur gene; no significant homology to the $E$. coli Fur-binding site was identified in either promoter. According to Northern blot analysis, the two fur transcripts were not strongly regulated by iron. DNA sequencing revealed a single open reading frame of 150 amino acids that was $76 \%$ homologous to the $E$. coli Fur protein.

\section{Vibrio anguillarum}

$V$. anguillarum is the causative agent of vibriosis, a widespread hemorrhagic septicemic disease in salmonid fishes. A major virulence factor for this bacterium is the presence of a specific plasmid, such as the $65-\mathrm{kbp}$ plasmid pJM1, that encodes a siderophore-mediated iron acquisition system (39). This system includes the outer membrane receptor protein OM2 (2) and the catechol siderophore anguibactin (1). Virulence of $V$. anguillarum is attenuated by mutations in this plasmid-mediated system that abolish anguibactin biosynthesis or OM2 production (151) or by absence of the entire plasmid (40).

Genetic analysis of plasmid pJM1 by insertion mutagenesis and lac $Z$ fusions identified six distinct genetic units that were required for the efficient uptake of iron. Five of these genetic units were essential for biosynthesis of the siderophore anguibactin (units I, III, IV, V, and VI). Bacteria containing mutations in the remaining genetic unit, unit II, were deficient in iron transport and produced reduced levels of anguibactin (144). Cloning, mutagenesis, and sequencing of genetic unit II localized the gene for OM2, the outer membrane protein essential for transport of iron by anguibactin, (144) and a gene encoding a $40-\mathrm{kDa}$ polypeptide, designated p40 (3).

Cloning and analysis of an area noncontiguous to the iron uptake region also identified genetic determinants for a trans-acting factor (taf) required for full expression of the anguibactin uptake system. Analysis of siderophore production and $\beta$-galactosidase activity of $l a c Z$ fusions suggested that Taf was a transcriptional activator of the siderophore biosynthetic genes (144). More recent evidence suggests that Taf may also activate the genes involved in transport of the ferric anguibactin complex into the cell (127).

In a survey of $V$. anguillarum isolates from different parts of the world, certain strains were identified as producing higher levels of the siderophore anguibactin. This increased siderophore production (Isp) was encoded by plasmids similar to pJM1, such as plasmid pJHC1. The gene responsible for the Isp phenotype was cloned from $\mathrm{pJHC1}$ and designated ang $R$; this gene encoded a $110-\mathrm{kDa}$ polypeptide product. Both the gene ang $R$ and its protein product were also found in strains containing pJM1, and ang $R$ mapped to the previously identified genetic unit III. The differences in ang $R$ that lead to the Isp phenotype in strains containing pJHC1 rather than pJM1 are not clear (127).

Analysis of specific RNA transcripts demonstrates that AngR and Taf regulate the production of anguibactin by activating transcription of the biosynthetic genes under iron-limiting conditions. Both AngR and Taf can act inde- pendently, but the factors together activate anguibactin biosynthesis in a synergistic manner (127).

Transcriptional analysis of $a n g R$ reveals that this gene itself is regulated by iron. The cloned $a n g R$ gene was sequenced, and a region upstream of $a n g R$ was found to have weak homology to the $E$. coli Fur consensus binding sequence. This suggests that a Fur-like protein is responsible for regulation of $a n g R$ transcription in the presence of iron. The deduced amino acid sequence of AngR predicts a helix-turn-helix motif in the protein that has homology to prokaryotic DNA-binding proteins (55), which is consistent with its role as a transcriptional activator.

\section{ROLE OF IRON IN THE VIRULENCE OF OTHER BACTERIA}

\section{Neisseria Species}

The genus Neisseria includes two species that cause infections in humans, Neisseria meningitidis and Neisseria gonorrhoeae. The importance of iron in infections with Neisseria spp. has been demonstrated in a variety of animal models. Studies by Holbein $(77,78)$ demonstrated that pretreatment of mice with iron dextran or ferric transferrin increased the risk of lethal septicemia following experimental infection with meningococci. Addition of iron to inocula of gonococci increased lethality for chicken embryos (120), while injection of the iron chelator desferroxamine protected chicken embryos from infection (57). Recently, Genco et al. isolated iron uptake mutants of $N$. gonorrhoeae that could not utilize transferrin or hemoglobin as the sole source of iron and showed that these mutants were avirulent in a mouse subcutaneous chamber model (63).

$N$. gonorrhoeae and $N$. meningitidis do not appear to produce siderophores $(5,112,156)$ but instead efficiently utilize a variety of host iron compounds. Meningococci and many gonococci utilize lactoferrin-bound iron (99). Both species can obtain sufficient iron for growth in vitro from transferrin $(5,97)$ as well as from hemoglobin $(100)$, hemin $(100,163)$, heme, and haptoglobin-bound hemoglobin (48). Iron acquisition from transferrin requires direct contact between transferrin and the organism (5) as well as ironregulated outer membrane proteins, one or more of which may function as specific receptors $(70,131)$.

One of the iron-regulated proteins in Neisseria spp. is synthesized in significantly greater amounts than the others and has been called the major iron-regulated protein, recently changed to $\mathrm{Fbp}$ (for iron-binding protein). The gene for Fbp has been cloned, characterized, and sequenced (10, 11). Fbp has a molecular mass of approximately $37 \mathrm{kDa}$ and is antigenically conserved among pathogenic species of Neisseria. The observation that iron copurifies with Fbp suggests that Fbp may play a role in iron acquisition; the presence of antibodies to Fbp in sera of patients with gonococcal infection suggests that $\mathrm{Fbp}$ is expressed in vivo and may play a role in neisserial pathogenicity (104).

Brener et al. (23) have reported a $69-\mathrm{kDa}$ iron-regulated protein in the outer membrane of $N$. meningitidis, while $N$. gonorrhoeae strains have been found to synthesize a number of outer membrane proteins in response to iron deprivation (156). Schryvers and Morris (131) identified a $71-\mathrm{kDa}$, ironregulated, transferrin-binding protein in $N$. meningitidis. A mutant of $N$. meningitidis that failed to utilize iron bound to transferrin or lactoferrin lacked a $70-\mathrm{kDa}$ iron-regulated protein (48).

Genetic evidence that $N$. gonorrhoeae produces specific 
receptors for transferrin and lactoferrin was provided by Blanton et al. (18), who isolated three phenotypic classes of mutants: those unable to utilize transferrin-bound iron (trf [transferrin receptor function]), those unable to utilize lactoferrin-bound iron (lrf [lactoferrin receptor function]), and those unable to utilize either ( $t l u$ [transferrin and lactoferrin utilization]). Each of these mutations appeared to be in a separate linkage group.

Two different meningococcal iron-repressible proteins (Frps) have been identified by their ability to bind human transferrin and have been designated TBP1 (transferrinbinding protein 1) and TBP2 (transferrin-binding protein 2) (118). Cornelissen et al. used polyclonal antiserum raised against gonococcal TBP1 to screen an expression library for fragments of the gene encoding TBP1, $t b p A$ (37). Simultaneously, part of a wild-type gene that repaired the defect in a trf mutant was cloned, and DNA sequencing revealed that the two clones overlapped. Transposon mutagenesis of both clones and recombination of mutagenized fragments into the gonococcal chromosome generated mutants that were incapable of growth on transferrin. No TBP1 was produced in these mutants, but TBP2 expression was normal. The complete amino acid sequence of $\mathrm{TbpA}$ was homologous to the class of TonB-dependent proteins in $E$. coli, suggesting a possible role for a meningococcal TonB-like protein in the utilization of transferrin.

\section{Yersinia Species}

In vitro growth of Yersinia species in iron-deficient medium results in the expression of several iron-regulated outer membrane proteins. Carniel et al. found that the degree of virulence of various Yersinia species correlated with the presence of two high-molecular-weight, iron-regulated membrane proteins (33). These two polypeptides were found to have common epitopes and to be antigenically related. Less pathogenic or nonpathogenic strains of Yersinia spp. did not exhibit cross-reacting material, suggesting that these strains did not synthesize altered forms of the high-molecularweight proteins (HMWP) (30). A portion of the gene encoding the smaller 190-kDa HMWP was cloned and used to probe various Yersinia species. Less pathogenic and nonpathogenic strains did not hybridize to the HMWP probe, suggesting that the absence of the gene rather than the lack of its expression was responsible for the failure of strains to synthesize HMWP (34).

Regulation of gene expression in Yersinia spp. by iron is mediated by a Fur protein homologous to that in $E$. coli. Carniel et al. found that the promoter for the $190-\mathrm{kDa}$ HMWP (irp2) is iron and Fur regulated in an $E$. coli background (32). Staggs and Perry (134) found that an E. coli iron-regulated $\beta$-galactosidase reporter construct was also iron regulated in $Y$. pestis. Chromosomal DNA of $Y$. pestis hybridized to an $E$. coli fur probe, and a cloned fragment of $Y$. pestis DNA complemented a Fur ${ }^{-}$phenotype in $E$. coli (134). The DNA sequence of the $Y$. pestis fur gene was determined recently (135); the gene exhibits $75 \%$ homology to the $E$. coli gene at the nucleotide level and $84 \%$ homology at the predicted amino acid level.

\section{CONCLUSIONS AND FUTURE DIRECTIONS}

The competitive growth and survival of bacteria in the host require a number of adaptive responses on the part of the bacteria; the acquisition of iron is one of the most important of these adaptive responses for bacterial patho- genesis. A shift from a high- to a low-iron environment is an important environmental signal to bacteria that they have entered a host. Bacteria respond to the low-iron environment by increasing expression of iron acquisition systems as well as of virulence determinants.

The molecular basis of coordinate regulation by iron has been most thoroughly studied in $E$. coli. In this organism, coordinate regulation of gene expression by iron depends on the repressor gene, fur. Fur-binding sites homologous to a 19-bp consensus sequence overlap the promoters of ironregulated genes. $\mathrm{Fe}^{2+}$ is a corepressor such that at sufficient intracellular concentrations of iron the Fur-iron complex binds to Fur-binding sites to prevent transcription. The work with $E$. coli provides a model of gene regulation that can be used to study the molecular mechanisms of regulation by iron in other bacterial species.

Most of the research on the mechanisms of regulation of virulence determinants by iron has been in gram-negative bacteria. Regulation of gene expression by iron in $V$. cholerae and $Y$. pestis is coordinated by proteins highly homologous to the Fur protein of $E$. coli. The fur genes of these two pathogens have been cloned and sequenced. Recent evidence also suggests that negative regulation of gene expression in $P$. aeruginosa by iron is mediated by a Fur homolog.

Relatively little is known concerning iron regulation in gram-positive bacteria. In this group, iron regulation has been primarily studied in $C$. diphtheriae. The gene $d t x R$ of $C$. diphtheriae has been cloned and shown to be responsible for the regulation of diphtheria toxin expression by iron. Homology between the deduced amino acid sequences of DtxR and Fur is quite limited, consistent with the finding that complementation between these two gene products is weak or absent. Despite similar mechanisms of action for DtxR and Fur, their binding sites may be limited to their species of origin. Further studies on iron regulation in gram-positive bacteria are needed.

Regulation of a number of virulence determinants by iron appears to be complex and requires more than one regulatory factor. Examples of this complex regulation include exotoxin A of $P$. aeruginosa, iron-regulated gene A (ing $A)$ of $V$. cholerae, and anguibactin of $V$. anguillarum. Additional regulatory proteins may be needed to provide the fine-tuning necessary for the precise regulation of individual virulence genes in response to iron and other environmental signals. Further studies of the interactions of iron and other environmental signals on virulence gene expression should lead to a better understanding of the adaptive responses of bacteria to the complex environment of their host.

\section{ACKNOWLEDGMENTS}

Preparation of the manuscript was supported by Public Health Service grant AI27329 from the National Institute of Allergy and Infectious Diseases to S.B.C. C.M.L. is the recipient of a National Research Service Award from the National Institute of Allergy and Infectious Diseases.

\section{REFERENCES}

1. Actis, L. A., W. Fish, J. H. Crosa, K. Kellerman, S. R. Ellenberger, F. M. Hauser, and J. Sanders-Loehr. 1986. Characterization of anguibactin, a novel siderophore from Vibrio anguillarum 775 (pJM1). J. Bacteriol. 167:57-65.

2. Actis, L. A., S. A. Potter, and J. H. Crosa. 1985. Iron-regulated outer membrane protein OM2 of Vibrio anguillarum is encoded by virulence plasmid PJM1. J. Bacteriol. 161:736-742.

3. Actis, L. A., M. E. Tolmasky, D. H. Farrell, and J. H. Crosa. 1988. Genetic and molecular characterization of essential com- 
ponents of the Vibrio anguillarum plasmid-mediated irontransport system. J. Biol. Chem. 263:2853-2860.

4. Aisen, P., and A. Leibman. 1972. Lactoferrin and transferrin: a comparative study. Biochim. Biophys. Acta 257:314-323.

5. Archibald, F. S., and I. W. DeVoe. 1979. Removal of iron from human transferrin by Neisseria meningitidis. FEMS Microbiol. Lett. 6:159-162.

6. Bagg, A., and J. B. Neilands. 1987. Molecular mechanism of regulation of siderophore-mediated iron assimilation. Microbiol. Rev. 51:509-518.

7. Bagg, A., and J. B. Neilands. 1987. Ferric uptake regulation protein acts as a repressor, employing iron(II) as a cofactor to bind the operator of an iron transport operon in Escherichia coli. Biochemistry 26:5471-5477.

8. Barry, D. M. J., and A. W. Reeve. 1977. Increased incidence of gram-negative neonatal sepsis with intramuscular iron administration. Pediatrics 60:908-912.

9. Becroft, D. M. O., M. R. Dix, and K. Farmer. 1977. Intramuscular iron-dextran and susceptibility of neonates to bacterial infections. Arch. Dis. Child. 52:778-781.

10. Berish, S. A., D. Kapczynski, and S. A. Morse. 1990. Nucleotide sequence of the Fbp gene from Neisseria meningitidis. Nucleic Acids Res. 18:4596.

11. Berish, S. A., T. A. Mietzner, L. W. Mayer, C. A. Genco, B. P. Holloway, and S. A. Morse. 1990. Molecular cloning and characterization of the structural gene for the major ironregulated protein expressed by Neisseria gonorrhoeae. J. Exp. Med. 171:1535-1546.

12. Beutler, B., and A. Cerami. 1987. Cachectin: more than a tumor necrosis factor. N. Engl. J. Med. 316:379-385.

13. Bindereif, A., and J. B. Neilands. 1985. Promoter mapping and transcriptional regulation of the iron assimilation system of plasmid ColV-K30 in Escherichia coli K-12. J. Bacteriol. 162:1039-1046.

14. Bindereif, A., P. E. Thorsness, and J. B. Neilands. 1983. Deletion mapping of the aerobactin gene complex of plasmid ColV. Inorganica. Chim. Acta 79:78-80.

15. Bjorn, M. J., B. H. Iglewski, S. K. Ives, J. C. Sadoff, and M. L. Vasil. 1978. Effect of iron on yields of exotoxin A in cultures of Pseudomonas aeruginosa PA-103. Infect. Immun. 19:785-791.

16. Bjorn, M. J., P. A. Sokol, and B. H. Iglewski. 1979. Influence of iron on yields of extracellular products in Pseudomonas aeruginosa cultures. J. Bacteriol. 138:193-200.

17. Blake, P. A., M. H. Merson, R. E. Weaver, D. G. Hollis, and P. C. Heublein. 1979. Disease caused by a marine vibrio: clinical characteristics and epidemiology. N. Engl. J. Med. 300:1-5.

18. Blanton, K. J., G. D. Biswas, J. Tsai, J. Adams, D. W. Dyer, S. M. Davis, G. G. Koch, P. K. Sen, and P. F. Sparling. 1990. Genetic evidence that Neisseria gonorrhoeae produces specific receptors for transferrin and lactoferrin. J. Bacteriol. 172:5225-5235.

19. Blumenthals, I. I., A. K. Skaja, R. M. Kelly, T. R. Clem, and J. Shiloach. 1987. Effect of culturing conditions on the production of exotoxin A by Pseudomonas aeruginosa. Ann. N.Y. Acad. Sci. 506:663-668.

20. Boyd, J., and J. R. Murphy. 1988. Analysis of the diphtheria tox promoter by site-directed mutagenesis. J. Bacteriol. 170: 5949-5952.

21. Boyd, J., M. N. Oza, and J. R. Murphy. 1990. Molecular cloning and DNA sequence analysis of a diphtheria tox irondependent regulatory element $(d t x R)$ from Corynebacterium diphtheriae. Proc. Natl. Acad. Sci. USA 87:5968-5972.

22. Braun, V., K. Hantke, K. Eick-Helmerich, W. Koster, U. Pressler, M. Sauer, S. Schafier, H. Schoffler, H. Staudenmaier, and L. Zimmermann. 1987. Iron transport systems in Escherichia coli, p. 35-51. In G. Winkelmann, D. van der Helm, and J. B. Neilands (ed.), Iron transport in microbes, plants and animals. VCH Publishers, Weinheim, Germany.

23. Brener, D., I. W. DeVoe, and B. E. Holbein. 1981. Increased virulence of Neisseria meningitidis after in vitro iron-limited growth at low pH. Infect. Immun. 33:59-66.

24. Brooks, H. J. L., F. O'Grady, M. A. McSherry, and W. R.
Cattel. 1980. Uropathogenic properties of Escherichia coli in recurrent urinary-tract infection. J. Med. Microbiol. 13:57-68.

25. Buck, G. A., R. E. Cross, T. P. Wong, J. Lorea, and N. Groman. 1985. DNA relationships among some tox-bearing corynebacteriophages. Infect. Immunol. 49:679-684.

26. Bullen, J. J., L. C. Leigh, and H. J. Rogers. 1968. The effect of iron compounds on the virulence of Escherichia coli for guinea-pigs. Immunology 15:581-588.

27. Bullen, J. J., H. J. Rogers, and E. Griffiths. 1978. Role of iron in bacterial infection. Curr. Top. Microbiol. Immunol. 80:1-35.

28. Calderwood, S. B., F. Auclair, A. Donohue-Rolfe, G. T. Keusch, and J. J. Mekalanos. 1987. Nucleotide sequence of the shiga-like toxin genes of Escherichia coli. Proc. Natl. Acad. Sci. USA 84:4364-4368.

29. Calderwood, S. B., and J. J. Mekalanos. 1987. Iron regulation of Shiga-like toxin expression in Escherichia coli is mediated by the fur locus. J. Bacteriol. 169:4759-4764.

30. Calderwood, S. B., and J. J. Mekalanos. 1988. Confirmation of the Fur operator site by insertion of a synthetic oligonucleotide into an operon fusion plasmid. J. Bacteriol. 170:1015-1017.

31. Carniel, E., J. C. Antoine, A. Guiyoule, N. Guiso, and H. H. Mollaret. 1989. Purification, location, and immunological characterization of the iron-regulated high-molecular-weight proteins of the highly pathogenic yersiniae. Infect. Immun. 57: 540-545.

32. Carniel, E., A. Guiyoule, I. Guilvout, and O. MercereauPuijalon. 1992. Molecular cloning, iron-regulation and mutagenesis of the irp2 gene encoding HMWP2, a protein specific for the highly pathogenic Yersinia. Mol. Microbiol. 6:379-388.

33. Carniel, E., D. Mazigh, and H. H. Mollaret. 1987. Expression of iron-regulated proteins in Yersinia species and their relation to virulence. Infect. Immun. 55:277-280.

34. Carniel, E., O. Mercereau-Puijalon, and S. Bonnefoy. 1989. The gene coding for the 190,000 -dalton iron-regulated protein of Yersinia species is present only in the highly pathogenic strains. Infect. Immun. 57:1211-1217.

35. Collier, R. J. 1967. Effect of diphtheria toxin on protein synthesis: inactivation of one of the transfer factors. J. Mol. Biol. 25:83-89.

36. Conradi, H. 1903. Ueber löshliche, durch aseptische Autolyse, erhaltene Giftstoffe von Ruhr-und Typhus Bazillen. Dtsch. Med. Wochenschr. 29:26-28.

37. Cornelissen, C. N., G. D. Biswas, J. Tsai, D. K. Paruchuri, S. A. Thompson, and P. F. Sparling. 1992. Gonococcal transferrin-binding protein 1 is required for transferrin utilization and is homologous to TonB-dependent outer membrane receptors. J. Bacteriol. 174:5788-5797.

38. Cowart, R. E., and B. G. Foster. 1985. Differential effects of iron on the growth of Listeria monocytogenes: minimum requirements and mechanism of acquisition. J. Infect. Dis. 151:721-730.

39. Crosa, J. H. 1980. A plasmid associated with virulence in the marine fish pathogen Vibrio anguillarum specifies an ironsequestering system. Nature (London) 284:566-568.

40. Crosa, J. H., L. L. Hodges, and M. H. Schiewe. 1980. Curing of a plasmid is correlated with an attenuation of virulence in the marine fish pathogen Vibrio anguillarum 775. Infect. Immun. 27:897-902.

41. DeBoy, J. M., I. K. Wachsmuth, and B. R. Davis. 1980. Hemolytic activity in enterotoxigenic and nonenterotoxigenic strains of Escherichia coli. J. Clin. Microbiol. 12:193-198.

42. De Grandis, S., J. Ginsburg, M. Toone, S. Climie, J. Friesen, and J. Brunton. 1987. Nucleotide sequence and promoter mapping of the Escherichia coli Shiga-like toxin operon of bacteriophage H-19B. J. Bacteriol. 169:4313-4319.

43. DeLorenzo, V., and J. B. Neilands. 1986. Characterization of iucA and iucC genes of the aerobactin system of plasmid ColV-K30 in Escherichia coli. J. Bacteriol. 167:350-355.

44. DeLorenzo, V., S. Wee, M. Herrero, and J. B. Neilands. 1987. Operator sequences of the aerobactin operon of plasmid ColV $\mathrm{K} 30$ binding the ferric uptake regulation (fur) repressor. $\mathbf{J}$. Bacteriol. 169:2624-2630.

45. Dinarello, C. A. 1984. Interleukin-1 and the pathogenesis of the 
acute-phase response. N. Engl. J. Med. 311:1413-1417.

46. Donohue-Rolfe, A., G. T. Keusch, C. Edson, D. ThorleyLawson, and M. Jacewicz. 1984. Pathogenesis of Shigella diarrhea. IX. Simplified high yield purification of Shigella toxin and characterization of subunit composition and function by the use of subunit-specific monoclonal and polyclonal antibodies. J. Exp. Med. 160:1767-1781.

47. Dubos, R. J., and J. W. Geiger. 1946. Preparation and properties of shiga toxin and toxoid. J. Exp. Med. 84:143-156.

48. Dyer, D. W., E. P. West, and P. F. Sparling. 1987. Effects of serum carrier proteins on the growth of pathogenic Neisseriae with heme-bound iron. Infect. Immun. 55:2171-2175.

49. Eaton, J. W., P. Brandt, J. R. Mahoney, and J. T. Lee. 1982. Haptoglobin: a natural bacteriostat. Science 215:691-692.

50. Eiklid, K., and S. Olsnes. 1983. Animal toxicity of Shigella dysenteriae cytotoxin. Evidence that the neurotoxic, enterotoxic, and cytotoxic activities are due to one toxin. J. Immunol. 130:380-384.

51. Endo, Y., K. Mitsui, M. Motizuki, and K. Tsurugi. 1987. The mechanism of action of ricin and related toxic lectins on eukaryotic ribosomes. J. Biol. Chem. 262:5908-5912.

52. Endo, Y., and K. Tsurugi. 1987. RNA $N$-glycosidase activity of ricin A-chain: mechanism of action of the toxic lectin ricin on eukaryotic ribosomes. J. Biol. Chem. 262:8128-8130.

53. Endo, Y., K. Tsurugi, T. Yutsudo, Y. Takeda, T. Ogasawara, and K. Igarashi. 1988. Site of action of a vero toxin (VT2) from Escherichia coli $\mathrm{O} 157: \mathrm{H} 7$ and of Shiga toxin on eukaryotic ribosomes: RNA $N$-glycosidase activity of the toxins. Eur. J. Biochem. 171:45-50.

54. Ernst, J. F., R. L. Bennett, and L. R. Rothfield. 1987. Constitutive expression of the iron-enterochelin and ferrichrome uptake systems in a mutant strain of Salmonella typhimurium. J. Bacteriol. 135:928-934.

55. Farrell, D. H., P. Mikesell, L. A. Actis, and J. H. Crosa. 1990 A regulatory gene, angR, of the iron uptake system of Vibrio anguillarum: similarity with phage P22 cro and regulation by iron. Gene 86:45-51.

56. Field, L. H., V. L. Headley, S. M. Payne, and L. J. Berry. 1986. Influence of iron on growth, morphology, outer membrane protein composition, and synthesis of siderophores in Campylobacter jejuni. Infect. Immun. 54:126-132.

57. Finkelstein, R. A., and R. J. Yancey. 1981. Effect of siderophores on virulence of Neisseria gonorrhoeae. Infect. Immun. 32:609-613.

58. Ford, A., and J. P. V. Hayhoe. 1976. An investigation of alternatives to hog gastric mucin as virulence-enhancing agents in the cholera vaccine potency assay. J. Biol. Stand. 4:353366.

59. Fourel, G., A. Phalipon, and M. Kaczorek. 1989. Evidence for direct regulation of diphtheria toxin gene transcription by an $\mathrm{Fe}^{2+}$-dependent DNA-binding repressor, DtoxR, in Corynebacterium diphtheriae. Infect. Immun. 57:3221-3225.

60. Frank, D. W., and B. H. Iglewski. 1988. Kinetics of toxA and regA mRNA accumulation in Pseudomonas aeruginosa. J. Bacteriol. 170:4477-4483.

61. Frank, D. W., D. G. Storey, M. S. Hindahl, and B. H. Iglewski. 1989. Differential regulation by iron of $\operatorname{reg} A$ and $\operatorname{tox} A$ transcript accumulation in Pseudomonas aeruginosa. J. Bacteriol. 171:5304-5313.

62. Frost, G. E., and H. Rosenberg. 1973. The inducible citratedependent iron transport system in Escherichia coli K-12. Biochim. Biophys. Acta 330:90-101.

63. Genco, C. A., C. Y. Chen, R. J. Arko, D. R. Kapczynski, and S. A. Morse. 1991. Isolation and characterization of a mutant of Neisseria gonorrhoeae that is defective in the uptake of iron from transferrin and haemoglobin and is avirulent in mouse subcutaneous chambers. J. Gen. Microbiol. 137:1313-1321.

64. Gladstone, G. P., and E. Walton. 1970. Effect of iron on the bactericidal proteins from rabbit polymorphonuclear leukocytes. Nature (London) 227:849-851.

65. Goldberg, M. B., S. A. Boyko, J. R. Butterton, J. A. Stoebner, S. M. Payne, and S. B. Calderwood. 1992. Characterization of a Vibrio cholerae virulence factor homologous to the family of
TonB-dependent proteins. Mol. Microbiol. 6:2407-2418.

66. Goldberg, M. B., S. A. Boyko, and S. B. Calderwood. 1990. Transcriptional regulation by iron of a Vibrio cholerae virulence gene and homology of the gene to the Escherichia coli Fur system. J. Bacteriol. 172:6863-6870.

67. Goldberg, M. B., S. A. Boyko, and S. B. Calderwood. 1991. Positive transcriptional regulation of an iron-regulated virulence gene in Vibrio cholerae. Proc. Natl. Acad. Sci. USA 88:1125-1129.

68. Goldberg, M. B., V. J. DiRita, and S. B. Calderwood. 1990. Identification of an iron-regulated virulence determinant in Vibrio cholerae, using TnphoA mutagenesis. Infect. Immun. 58:55-60.

69. Grant, C. C. R., and M. L. Vasil. 1986. Analysis of transcription of the exotoxin A gene of Pseudomonas aeruginosa. J. Bacteriol. 168:1112-1119.

70. Griffiths, E., P. Stevenson, and A. Ray. 1990. Antigenic and molecular heterogeneity of the transferrin-binding protein of Neisseria meningitidis. FEMS Microbiol. Lett. 69:31-36.

71. Hantke, K. 1981. Regulation of ferric iron transport in Escherichia coli K12: isolation of a constitutive mutant. Mol. Gen. Genet. 182:288-292.

72. Hantke, K. 1984. Cloning of the repressor protein gene of iron-regulated systems in Escherichia coli K-12. Mol. Gen. Genet. 197:337-341.

73. Hart, R. C., S. Kadis, and W. L. Chapman. 1982. Nutritional iron status and susceptibility to Proteus mirabilis pyelonephritis in the rat. Can. J. Microbiol. 28:713-717.

74. Helms, S. D., J. D. Oliver, and J. C. Travis. 1984. Role of heme compounds and haptoglobin in Vibrio vulnificus pathogenicity. Infect. Immun. 45:345-349.

75. Henikoff, S., G. W. Haughn, J. M. Calvo, and J. C. Wallace. 1988. A large family of bacterial activator proteins. Proc. Natl. Acad. Sci. USA 85:6602-6606.

76. Hindahl, M. S., D. W. Frank, and B. H. Iglewski. 1987. Molecular studies of a positive regulator of toxin A synthesis in Pseudomonas aeruginosa. Antibiot. Chemother. (Washington, D.C.) 39:279-289.

77. Holbein, B. E. 1980. Iron-controlled infection with Neisseria meningitidis in mice. Infect. Immun. 29:886-891.

78. Holbein, B. E. 1981. Enhancement of Neisseria meningitidis infection in mice by addition of iron bound to transferrin. Infect. Immun. 34:120-125.

79. Honjo, T., Y. Nishizuka, I. Kato, and O. Hayaishi. 1971. Adenosine diphosphate ribosylation of aminoacyl transferase II and inhibition of protein synthesis by diphtheria toxin. J. Biol. Chem. 246:4251-4260.

80. Iglewski, B. H., and D. Kabat. 1975. NAD-dependent inhibition of protein synthesis by Pseudomonas aeruginosa toxin. Proc. Natl. Acad. Sci. USA 72:2284-2288.

81. Johnson, W. M., H. Lior, and G. S. Bezanson. 1983. Cytotoxic Escherichia coli $\mathrm{O} 157: \mathrm{H} 7$ associated with haemorrhagic colitis in Canada. Lancet i:76.

82. Kaczorek, M., G. Zettlmeissl, F. Delpeyrux, and R. E. Streeck. 1985. Diphtheria toxin promoter function in Corynebacterium diphtheriae and Escherichia coli. Nucleic Acids Res. 13:31473159.

83. Kanei, C., T. Uchida, and M. Yoneda. 1977. Isolation from Corynebacterium diphtheriae $\mathrm{C7}(\beta)$ of bacterial mutants that produce toxin in medium with excess iron. Infect. Immunol. 18:203-209.

84. Karmali, M. A., M. Petric, C. Lim, P. Fleming, G. Arbus, and H. Lior. 1985. The association between idiopathic hemolytic uremic syndrome and infection by Verotoxin-producing $E s$ cherichia coli. J. Infect. Dis. 151:775-782.

85. Keown, P., and B. Descamps-Latscha. 1983. In vitro suppression of cell-mediated immunity by ferroproteins and ferric salts. Cell. Immunol. 80:257-266.

86. Lawlor, K. M., P. A. Daskaleros, R. E. Robinson, and S. M. Payne. 1987. Virulence of iron transport mutants of Shigella flexneri and utilization of host iron compounds. Infect. Immun. 55:594-599.

87. Lawlor, K. M., and S. M. Payne. 1984. Aerobactin genes in 
Shigella spp. J. Bacteriol. 160:266-272.

88. Leffel, M. S., and J. K. Spitznagel. 1975. Fate of human lactoferrin and myeloperoxidase in phagocytizing human neutrophils: effects of immunoglobulin G subclasses and immune complexes coated on latex beads. Infect. Immun. 12:813-820.

89. Leong, D., and J. R. Murphy. 1985. Characterization of the diphtheria tox transcript in Corynebacterium diphtheriae and Escherichia coli. J. Bacteriol. 163:1114-1119.

90. Linggood, M. A., and P. L. Ingram. 1982. The role of alpha haemolysin in the virulence of Escherichia coli for mice. J. Med. Microbiol. 15:23-30.

91. Litwin, C. M., S. A. Boyko, and S. B. Calderwood. 1992. Cloning, sequencing, and transcriptional regulation of the Vibrio cholerae fur gene. J. Bacteriol. 174:1897-1903.

92. Liu, P. V. 1973. Exotoxins of Pseudomonas aeruginosa. I. Factors that influence the production of exotoxin A. J. Infect. Dis. 128:506-513.

93. Lory, S. 1986. Effect of iron on accumulation of exotoxin A-specific mRNA in Pseudomonas aeruginosa. J. Bacteriol. 168:1451-1456.

94. Marolda, C. L., M. A. Valvano, K. M. Lawlor, S. Payne, and J. H. Crosa. 1987. Flanking and internal regions of chromosomal genes mediating aerobactin iron uptake systems in enteroinvasive Escherichia coli and Shigella flexneri. J. Gen. Microbiol. 133:2269-2278.

95. Marques, L. R. M., J. S. M. Peiris, S. J. Cryz, and A. D. O'Brien. 1987. Escherichia coli strains isolated from pigs with edema disease produce a variant of Shiga-like toxin II. FEMS Microbiol. Lett. 44:33-38.

96. McDuggall, S., and J. B. Neilands. 1984. Plasmid- and chromosome-coded aerobactin synthesis in enteric bacteria: insertion sequences flank operon in plasmid-mediated systems. J. Bacteriol. 159:300-305.

97. McKenna, W. R., P. A. Mickelsen, P. F. Sparling, and D. W. Dyer. 1988. Iron uptake from lactoferrin and transferrin by Neisseria gonorrhoeae. Infect. Immun. 56:785-791.

98. Melby, K. L., S. Slordahl, T. J. Gutterberg, and S. A. Nordbo. 1982. Septicaemia due to Yersinia enterocolitica after oral overdoses of iron. Br. Med. J. 285:467-468.

99. Mickelsen, P. A., E. Blackman, and P. F. Sparling. 1982. Ability of Neisseria gonorrhoeae, Neisseria meningitidis, and commensal Neisseria species to obtain iron from lactoferrin. Infect. Immun. 35:915-920.

100. Mickelsen, P. A., and P. F. Sparling. 1981. Ability of Neisseria gonorrhoeae, Neisseria meningitidis, and commensal Neisseria species to obtain iron from transferrin and iron compounds. Infect. Immun. 33:555-564.

101. Middlebrook, J. L., and R. B. Dorland. 1977. Response of cultured mammalian cells to the exotoxins of Pseudomonas aeruginosa and Corynebacterium diphtheriae: differential cytotoxicity. Can. J. Microbiol. 23:183-189.

102. Miller, J. F., J. J. Mekalanos, and S. Falkow. 1989. Coordinate regulation and sensory transduction in the control of bacterial virulence. Science 243:916-922.

103. Minshew, B. H., J. Jorgensen, G. W. Counts, and S. Falkow. 1978. Association of hemolysin production, hemagglutination of human erythrocytes, and virulence for chicken embryos of extraintestinal Escherichia coli isolates. Infect. Immun. 20:5054.

104. Morse, S. A., C. Chen, A. LeFaou, and T. A. Mietzner. 1988. A potential role for the major iron-regulated protein expressed by pathogenic Neisseria species. Rev. Infect. Dis. 10(Suppl. 2): s306-s310.

105. Muller, D., M. L. Edwards, and D. W. Smith. 1983. Changes in iron and transferrin levels and body temperature in experimental airborne legionellosis. J. Infect. Dis. 147:302-307.

106. Murphy, J. R., and P. Bacha. 1979. Regulation of diphtheria toxin production, p. 181-186. In D. Schlessinger (ed.), Microbiology-1979. American Society for Microbiology, Washington, D.C.

107. Murphy, J. R., J. Skiver, and G. McBride. 1976. Isolation and partial characterization of a corynebacteriophage $\beta$, tox operator constitutive-like mutant lysogen of Corynebacterium diph- theriae. J. Virol. 18:235-244.

108. Neilands, J. B. 1972. Evolution of biological iron binding centers. Struct. Bond. 11:145-170.

109. Neilands, J. B. 1981. Microbial iron compounds. Annu. Rev. Biochem. 50:715-731.

110. Neilands, J. B. 1982. Microbial envelope proteins related to iron. Annu. Rev. Microbiol. 36:285-309.

111. Neilands, J. B. 1990 . Molecular biology and regulation of iron acquisition by Escherichia coli K12, p. 205-223. In B. H. Iglewski and V. L. Clark (ed.), Molecular basis of bacterial pathogenesis. Academic Press, Inc., San Diego, Calif.

112. Norrod, P., and R. P. Williams. 1978. Growth of Neisseria gonorrhoeae in media deficient in iron without detection of siderophores. Curr. Microbiol. 1:281-284.

113. O'Brien, A. D., and G. D. LaVeck. 1983. Purification and characterization of a Shigella dysenteriae 1-like toxin produced by Escherichia coli. Infect. Immun. 40:675-683.

114. O'Brien, A. D., G. LaVeck, M. R. Thompson, and S. B. Formal. 1982. Production of Shigella dysenteriae type 1-like cytotoxin by Escherichia coli. J. Infect. Dis. 146:763-769.

115. O'Brien, A. D., J. W. Newland, S. F. Miller, R. K. Holmes, H. W. Smith, and S. F. Formal. 1984. Shiga-like toxin-converting phages from Escherichia coli strains that cause hemorrhagic colitis or infantile diarrhea. Science 226:694-696.

116. Olsnes, S., R. Reisbig, and K. Eiklid. 1981. Subunit structure of Shigella cytotoxin. J. Biol. Chem. 256:8732-8738.

117. Opal, S. M., A. S. Cross, P. Gemski, and L. W. Lyhte. 1990. Aerobactin and $\alpha$-hemolysin as virulence determinants in Escherichia coli isolated from human blood, urine, and stool. J. Infect. Dis. 161:794-796.

118. Padda, J. S., and A. B. Schryvers. 1990. N-linked oligosaccharides of human transferrin are not required for binding to bacterial transferrin receptors. Infect. Immun. 58:2972-2976.

119. Pappenheimer, A. M., Jr., and S. J. Johnson. 1936. Studies in diphtheria toxin production. I. The effect of iron and copper. Br. J. Exp. Pathol. 17:335-341.

120. Payne, S. M., and R. A. Finkelstein. 1975. Pathogenesis and immunology of experimental gonococcal infection: role of iron in virulence. Infect. Immun. 12:1313-1318.

121. Perry, R. D., and R. R. Brubaker. 1979. Accumulation of iron by Yersiniae. J. Bacteriol. 137:1290-1298.

122. Prince, R. W., D. G. Storey, A. I. Vasil, and M. L. Vasil. 1991. Regulation of $\operatorname{tox} A$ and regA by the Escherichia coli fur gene and identification of a Fur homologue in Pseudomonas aeruginosa PA103 and PAO1. Mol. Microbiol. 5:2823-2831.

123. Puschmann, M., and A. M. Ganzoni. 1977. Increased resistance of iron-deficient mice to Salmonella infection. Infect. Immun. 17:663-664.

124. Reisbig, R., S. Olsnes, and K. Eiklid. 1981. The cytotoxic activity of Shigella toxin: evidence for catalytic inactivation of the 60S ribosomal subunit. J. Biol. Chem. 256:8739-8744.

125. Robins-Browne, R. M., and J. K. Prpic. 1985. Effects of iron and desferroxamine on infections with Yersinia enterocolitica. Infect. Immun. 47:774-779.

126. Russell, L. M., S. J. Cryz, and R. K. Holmes. 1984. Genetic and biochemical evidence for a siderophore-dependent iron transport system in Conynebacterium diphtheriae. Infect. Immun. 45:143-149.

127. Salinas, P. C., M. E. Tolmasky, and J. H. Crosa. 1989. Regulation of the iron uptake system in Vibrio anguillarum: evidence for a cooperative effect between two transcriptional activators. Proc. Natl. Acad. Sci. USA 86:3529-3533.

128. Saxena, S. K., A. D. O'Brien, and E. J. Ackerman. 1989. Shiga toxin, Shiga-like toxin II variant, and ricin are all single-site RNA $N$-glycosidases of $28 \mathrm{~S}$ RNA when microinjected into Xenopus oocytes. J. Biol. Chem. 264:596-601.

129. Schaffer, S., K. Hantke, and V. Braun. 1985. Nucleotide sequence of the iron regulatory gene fur. Mol. Gen. Genet. 200:110-113.

130. Schmitt, M. P., and R. K. Holmes. 1991. Iron-dependent regulation of diphtheria toxin and siderophore expression by the cloned Corynebacterium diphtheriae repressor gene $d t x R$ in C. diphtheriae C7 strains. Infect. Immun. 59:1899-1904. 
131. Schryvers, A. B., and L. J. Morris. 1988. Identification and characterization of the transferrin receptor from Neisseria meningitidis. Mol. Microbiol. 2:281-288.

132. Smith, H. W. 1963. The haemolysins of Escherichia coli. J. Pathol. Bacteriol. 85:197-211.

133. Sokol, P. A., C. D. Cox, and B. H. Iglewski. 1982. Pseudomonas aeruginosa mutants altered in their sensitivity to the effect of iron on toxin A or elastase yields. J. Bacteriol. 151:783-787.

134. Staggs, T. M., and R. D. Perry. 1991. Identification and cloning of a fur regulatory gene in Yersinia pestis. J. Bacteriol. 173:417-425.

135. Staggs, T. M., and R. D. Perry. 1992. Fur regulation in Yersinia species. Mol. Microbiol. 6:2507-2516.

136. Stoebner, J. A., and S. M. Payne. 1988. Iron-regulated hemolysin production and utilization of heme and hemoglobin by Vibrio cholerae. Infect. Immun. 56:2891-2895.

137. Storey, D. G., T. L. Raivio, D. W. Frank, M. J. Wick, S. Kaye, and B. H. Iglewski. 1991. Effect of regB on expression from the $\mathrm{P} 1$ and $\mathrm{P} 2$ promoters of the Pseudomonas aeruginosa reg $A B$ operon. J. Bacteriol. 173:6088-6094.

138. Strockbine, N. A., M. P. Jackson, L. M. Sung, R. K. Holmes, and A. D. O'Brien. 1988. Cloning and sequencing of the gene for Shiga toxin from Shigella dysenteriae type 1. J. Bacteriol. 170:1116-1122.

139. Strockbine, N. A., L. R. M. Marques, J. W. Newland, H. W. Smith, R. K. Holmes, and A. D. O'Brien. 1986. Two toxinconverting phages from Escherichia coli $\mathrm{O} 157: \mathrm{H} 7$ strain 933 encode antigenically distinct toxins with similar biologic activities. Infect. Immun. 53:135-140.

140. Stull, T. L. 1987. Protein sources of heme for Haemophilus influenzae. Infect. Immun. 55:148-153.

141. Sung, L. M., M. P. Jackson, A. D. O'Brien, and R. K. Holmes. 1990. Transcription of the Shiga-like toxin type II and Shigalike toxin type II variant operons of Escherichia coli. J. Bacteriol. 172:6386-6395.

142. Tai, S. P., and R. K. Holmes. 1988. Iron regulation of the cloned diphtheria toxin promoter in Escherichia coli. Infect. Immun. 56:2430-2436.

143. Tai, S. P., A. E. Krafit, P. Nootheti, and R. K. Holmes. 1990. Coordinate regulation of siderophore and diphtheria toxin production by iron in Corynebacterium diphtheriae. Microb. Pathog. 9:267-273.

144. Tolmalsky, M. E., P. C. Salinas, L. A. Actis, and J. H. Crosa. 1988. Increased production of the siderophore anguibactin mediated by pJM1-like plasmids in Vibrio anguillarum. Infect. Immun. 56:1608-1614.

145. Tullus, K., S. H. Jacobson, M. Katouliana, and A. Brauner. 1991. Relative importance of eight virulence characteristics of pyelonephritogenic Escherichia coli strains assessed by multivariate statistical analysis. J. Urol. 146:1153-1155.

146. Uchida, T., D. M. Gill, and A. M. Pappenheimer, Jr. 1971. Mutation in the structural gene for diphtheria toxin carried by temperate phage $\beta$. Nature (London) New Biol. 233:8-11.

147. Valvano, M. A., and J. H. Crosa. 1984. Aerobactin iron transport genes commonly encoded by certain ColV plasmids occur in the chromosome of a human invasive strain of Escherichia coli $\mathrm{K} 1$. Infect. Immun. 46:159-167.

148. Van Heyningen, W. E., and G. P. Gladstone. 1953. The neurotoxin of Shigella shigae. 3. The effect of iron on production of the toxin. Br. J. Exp. Pathol. 34:221-229.

149. Van Snick, J. L., P. L. Masson, and J. F. Heremans. 1974. The involvement of lactoferrin in the hyposideremia of acute inflammation. J. Exp. Med. 140:1068-1614.

150. Waalwijk, C., D. M. MacLaren, and J. deGraaff. 1983. In vivo function of hemolysin in the nephropathogenicity of Escherichia coli. Infect. Immun. 42:245-249.

151. Walter, M. A., S. A. Potter, and J. H. Crosa. 1983. Iron uptake system mediated by Vibrio anguillarum plasmid pJM1. J. Bacteriol. 156:880-887.

152. Ward, C. G., J. S. Hammond, and J. J. Bullen. 1986. Effect of iron compounds on antibacterial function of human polymorphs and plasma. Infect. Immun. 51:723-730.

153. Warner, P. J., P. H. Williams, A. Bindereif, and J. B. Neilands. 1981. ColV plasmid-specified aerobactin synthesis by invasive strains of Escherichia coli. Infect. Immun. 33:540-545.

154. Weinberg, E. D. 1984. Iron witholding: a defense against infection and neoplasia. Physiol. Rev. 64:65-102.

155. Welkos, S., and R. K. Holmes. 1981. Regulation of toxinogenesis in Corynebacterium diphtheriae. I. Mutations in bacteriophage $\beta$ that alter the effects of iron on toxin production. $J$. Virol. 37:936-945.

156. West, S. E. H., and P. F. Sparling. 1985. Response of Neisseria gonorrhoeae to iron limitation: alterations in expression of membrane proteins without apparent siderophore production. Infect. Immun. 47:388-394.

157. Williams, P. H. 1979. Novel iron uptake system specified by ColV plasmids: an important component in the virulence of invasive strains of Escherichia coli. Infect. Immun. 26:925932.

158. Williams, P. H., and P. J. Warner. 1980. ColV plasmidmediated, colicin V-independent iron uptake system of invasive strains of Escherichia coli. Infect. Immun. 29:411-416.

159. Wochner, R. D., I. Spilberg, A. Iio, H. H. Liem, and U. Muller-Eberhard. 1974. Hemopexin metabolism in sickle cell disease, porphyrias and control subjects-effects of heme injection. N. Engl. J. Med. 290:822-826.

160. Woods, D. E., and B. H. Iglewski. 1983. Toxins of Pseudomonas aeruginosa: new perspectives. Rev. Infect. Dis. 5:S715S722.

161. Wright, A. C., L. M. Simpson, and J. D. Oliver. 1981. Role of iron in the pathogenesis of Vibrio vulnificus infections. Infect. Immun. 34:503-507.

162. Wright, D. G., and J. I. Gallin. 1979. Secretory responses of human neutrophils: exocytosis of specific (secondary) granules by human neutrophils during adherence in vitro and during exudation in vivo. J. Immunol. 123:285-294.

163. Yancey, R. J., and R. A. Finkelstein. 1981. Assimilation of iron by pathogenic Neisseria spp. Infect. Immun. 32:592-599. 